\title{
Motivational Factors and its Influence on the Job Performance of Non-academic Staff in a University
}

\author{
${ }^{1}$ Minerva C. Manalo \& ${ }^{2}$ Elaine Joy C. Apat
}

\begin{abstract}
The human capital is unarguably an important element that completes any organization. With proper motivation, these people work towards quality products and services. Question arises on non-teaching personnel of academic institutions as support staff. This study focuses on the work motivations and job performance of non-teaching personnel in a university. This descriptive research used structured questionnaire for the self-assessment of the 50 administrative and support staff. The results of the study proved that the workplace environment and professional growth and development are considered highly influential motivational factors. Furthermore, there is a positive significant relationship between the motivational factors and job performance as to quantity and quality of work. It also confirmed that professional growth and development has significant relations with the attitude towards work. The results of this study can be an input to the University Human Resource planning. Since the study is focused only on a single university, a comparative study with another higher education institution is recommended.
\end{abstract}

Keywords:

motivation, job performance, rewards, salaries, attitude, work quality

Suggested Citation: Manalo, M.C. \& Apat, E.C. (2021). Motivational Factors and its Influence on the Job Performance of Non-academic Staff in a University. International Journal of Academe and Industry Research, Volume 2, Issue 3, pp. 48-63.

\footnotetext{
About the author:

${ }^{1}$ Corresponding author. Instructor I, Laguna State Polytechnic University- San Pablo City, Philippines

${ }^{2}$ Instructor I, Laguna State Polytechnic University- San Pablo City, Philippines
} 


\section{Introduction}

The success of any organization lies from the effective work performance of its human assets. There are multitude of factors contributing to the quality of work performance such as efficiency, ability, motivation and organizational engagement. Any of these factors could lead to some work issues. The common indications of poor employee performance are frequency of work transfer, high rate of resignation, dismissal and hiring and high instances of complaints. These could eventually lead to organizational failure in terms of attainment of the objectives. On the other hand, organizations with motivated personnel who are willing to work an extra mile, appreciate the nature of the job and work with passion seemingly manifest proper motivation in the work place. The motivation in the workplace can be an attribute of an individual's personality. For instance, self-willingness, life progress, and positive work attitudes maybe a product of an employees' liking of the task matched with the skills and abilities. These could also be affected by co-workers, organization culture and working environment.

In an educational institution, the personnel are generally classified as academic (teaching staff) and non-academic (administrative and support staff). While it is obvious that the academic staff directly connect with the key stakeholders such as students and parents, the non-academic staff provide sufficient amount of non-academic support that enhances the quality of service delivery. For instance, the various offices such as Human Resource, Accounting, Cashier, Registrar, Student Affairs, Guidance, Facilities, and Sports among others are tasked with important objectives necessary for the effective delivery of academic concerns. Most often than not, these support staff are neglected as described by Lau (2010) that these employees received little attention in the scholarly literature.

Ogunode, Godwin and Ajape (2021) identified poor motivation and staff development as common issues faced by non-academic staff in higher education institutions. While it can be viewed that motivation differs from the needs of an employee, there are organizational factors that induce motivation. Thus this study aims to determine how the non-academic staff performance has been motivated by workplace environment, professional growth and development, promotion, salaries and rewards or incentives. Similarly, it correlates these motivational factors to job performance measures such as quality, quantity and attitude towards work.

\section{Literature Review}

According to McShane and Glinow (2010), motivation is 'the force within a person that affects the direction, intensity and persistence of voluntary behavior in which a motivated person are willing to exert a particular level of effort for a certain amount of time in order to complete the task given effectively'. Employee motivation is an important part of human resource management because it is directly linked to job performance (Noor et.al, 2020; 
Wanjiku, 2016; Aideed Bashir, et.al, 2020)). As motivation induces people to perform a task, motivated employees work harder and achieve better output in less time thereby reducing labor costs (Delgado, Yap \& Luces, 2018). Moreover, motivated employees require less supervision and demonstrate pride in its work, making a greater impact on the customer (Seng \& Choi, 2016). These staff will also have greater concentration; hence, they are less likely to make mistakes, cause accidents or be involved in a conflict. Highly motivated personnel are likely to show greater loyalty to the company and lesser absenteeism (Lau, 2010). Gichure (2014) identified extrinsic factors such as work environment and condition, pay and fringe benefits that affect employee performance of non-academic staff. Meanwhile, Doan Hong Lea, et.al (2021) added salary, colleague, training and promotion as positively and significantly affecting employee performance. All these variables were included and briefly discussed in the current study.

\subsection{Workplace Environment}

The workplace environment impacts employee morale, productivity and engagement both positively and negatively (Chandrasekar, 2011). The unsafe and unhealthy workplace environment is characterized by poorly designed workstation, insufficient safety measures in fire emergencies and lack of personal protective equipment. People working in such environment are prone to occupational disease that generally affects employee performance. These workplace scenarios decrease productivity due to the work atmosphere. It is the quality of the employee's work situation that affects the level of motivation and subsequent performance.

The workplace environment is considered crucial in terms of employee satisfaction due to the fast-paced technological changes. There are various considerations on the physical setup as well as the social atmosphere in the workplace. With technological development, innovative communication methods, and alternative work patterns, workplace continues to change rapidly. Several studies approve that the workplace environment affects employee work performance. The statistical test conducted by Muchtar (2016) resulted to $t=2,376$; and $\mathrm{p}=0.021(\mathrm{p}<0.05)$ which signify that working environment has a significant effect on employee performance. Similary, Naharuddin (2013) and Norlina, et.al (2020) got the same analytical results that physical workplace environment has significant relationship towards the employees' performance. This was further elaborated by Bushiri (2021) that performance improves whenever problems are addressed such as flexibility, work noise, supervisor's interpersonal relationship and work incentives.

Creating a work environment in which employees are going to be productive is essential to increasing better output provided by any organization, corporation or small businesses. The relationship between work, the workplace and the tools of work, workplace becomes an integral part of work itself (Aideed Bashir, 2020). The management that dictates 
how to take full advantage of employee productivity center around two major areas of focus: personal motivation and the infrastructure of the work environment.

\subsection{Professional Growth and Development}

Training programs play a vital role in the employee growth and development. There are several employee benefits generated from training programs such as improve employee performance, update employee knowledge, and enhance personal skills. With these programs, it is easier for management to evaluate the job performance and accordingly take decisions on issues like employee promotion, rewards, compensation, and welfare facilities among other things. These training programs help the managers or senior officials in succession planning, employee retention and motivation. According to Adejare, et.al (2020), universities can develop the non-academic staff by providing comprehensive job-specific training. The university management must conduct job-specific assessment and performance evaluation to assess the type of training needed.

According to Truitt (2011), organizations are responsible for the design, implementation and evaluation of the training programs in order to reduce performance disputes. In the study, it was found that a person's positive training experience and attitude are significantly related. Relatively, Raja, Furqan and Muhammad (2011) shown that training develops employees to be problem-solvers and decision makers. These also develop the interpersonal skills enabling personnel to collaborate and work together to achieve organization and personal goals. Therefore, training nonacademic staff on the use of some technology to get the job done is not a question required for debate but a must for an organization who want to excel both in the local and foreign environment (Adejare, et.al, 2020).

\subsection{Promotion}

Hasibuan (2018) defines promotion as movement from one position to anothr with associated higher status and responsibility and increased monetary benefits. According to Raja (2011), promotion is considered a reward for a work well-done and a recognition of the employee's contribution and commitment to the organization. Gupta (2011) adds that promotion encourages employees to improve their work performance to get career advancement. As a result, employees get satisfied once promotion is achieved. Getting promoted to a higher position is a desire of each employee. Several common factors are considered in promoting an employee such as work performance, seniority, loyalty level, honesty and other behavior (Gede Purnawan Adi et.al, 2016). However, promotion comes with increased accountability and responsibility. This type of incentive motivates the employee to put forth all efforts to win management's trust and confidence.

According to Kosteas (2009), the importance of promotions as a mechanism for eliciting greater effort from workers can be better understood by estimating the effect of both 
promotions and promotion expectations on job satisfaction. Even after controlling for wages and wage increases, finding that promotions lead to higher job satisfaction supports the idea that workers value the promotion itself. Firms now have a non-monetary tool to elicit effort and other positive behavior from their employees. Accurate estimates of these effects can show how effective promotions are at motivating people to work harder. Furthermore, promotion expectations can have a significant impact. Workers who realize they will not be promoted this time around may reduce their work effort unless they believe they will be promoted in the future.

In a study conducted by Rinny, Purba and Handiman (2020), the compensation, job promotions and job satisfaction were found to have significant effect on performance. In particular, promotion has a positive and significant effect on performance. It was also found by Rahayu (2017) that promotion has a positive and significant influence on performance. Similar results were obtained by Simanjuntak (2015) on the positive significant influence of job promotion to job performance while Septiani (2015) found that job promotion influences performance.

\subsection{Salaries}

According to Hasibuan (2018), salary includes direct compensation (salary, wages, and incentives) and indirect compensation (employee welfare). For Elmi (2018), this could be financial or non-financial.

According to Rahman and Hoque (2014), one of the best motivators is salary or pay. As reiterated by Asaari and Desa (2019), this pertains to the safety requirements in accordance to the Maslow's hierarchy of needs. This must be met in order to have a job that is guaranteed, treated fairly, and pays a decent wage. As an extrinsic reward, salary plays an important role in ensuring employees are motivated, thorough, loyal, and sincere to their work (Bullock, Stritch \& Rainey, 2015). Relative to this, Pigors and Meyer (2007), suggest that payments be based on outputs. Though there are many reasons people work for a living, it is undeniable that money and other financial reward play a key role in motivating people in the workplace.

There are several studies that attest to the positive effect of salary to work performance. Fauzi (2014) found that financial and nonfinancial compensation had a positive and significant influence on employee performance. This was supported by the studies of Hamran Mohamad et. al (2016) and Yuli Triana (2017) that compensation has significant influence on work performance.

\subsection{Rewards and Incentives}

Incentives are motivating force that initiates the employees to do some action for the organization. The employees usually carry on providing high performance if the incentives are available but stop if incentives disappear. According to Eshun and Duah (2011), employee satisfaction with rewards is inextricably linked to what the employee expects from the 
organization versus what he or she receives. Employees' feelings of satisfaction or dissatisfaction arise when their inputs, such as education, job skills, and effort, are compared to the mix of intrinsic and extrinsic rewards they receive from their employers.

As introduced by Cooke (2011), incentive-based tools or instruments can be used to encourage people to change behavior or actions in a prescribed manner. An incentive can be defined as the offer of a reward before performance of a behavior, which is designed to induce a desired behavior. Incentives may be taking many forms from the financial to the reputational. Similarly, disincentives threaten some form of punishment if a behavior is performed. For instance, Baskar (2015) states that recognition makes employees feel valued and appreciated. Employees who are recognized have higher self-esteem, more confidence, are more willing to take on new challenges, and are more eager to be innovative.

Employee motivation can be channeled in desired ways using a reward system. In other words, reward systems are designed to entice people to join an organization, keep them coming to work, and motivate them to achieve high levels of performance. All organization components, including people processes, rules, and decision-making activities, are part of the reward system. It involves the allocation of compensation and benefits to employees in exchange for their contributions to the organization.

\section{Methodology}

This study is a descriptive type of research. It is a fact-finding study with adequate and accurate interpretation in finding. This method was utilized to know the work motivations and its relation to the job performance of the non - teaching staff in the university.

Due to COVID-19 pandemic restrictions, the study focused only on the San Pablo City Campus instead of all the campuses of a public university in Laguna Province in the Philippines. The whole population of 66 non - teaching staff were study participants however only 50 accomplished survey questionnaires were retrieved. This gives a retrieval rate of $78 \%$. The participants of the study belongs to the age bracket of 28 to 25 (28\%), 26 to 35 (50\%), 36 to $35(18 \%)$ and 46 to $55(4 \%)$. In terms of gender, $68 \%$ are female while $32 \%$ are male.

The main tool for data gathering is a self-structured questionnaire. It is divided into three parts: 1) profile of the respondents; 2) assessment on the motivation factors in terms of workplace environment, professional growth and development, advancement and salaries and benefits and 3) assessment of the job performance in terms of quality, quantity and attitude towards the job.

The data gathering was coursed through the Human Resource Office for the distribution of the questionnaire. Upon approval by the HR officer, the hard copy of the questionnaire was distributed to the total population. The accomplished questionnaires were retrieved days later. 
International Journal of Academe and Industry Research, Volume 2 Issue 3

Frequency count, weighted mean and Pearson - $r$ were used for data analysis.

\section{Findings and Discussion}

\section{Table 1}

Self-perception on Motivational Factors

\begin{tabular}{cccc}
\hline Factors & $\overline{\boldsymbol{X}}$ & SD & VI \\
\hline Workplace Environment & 4.44 & 0.36 & Highly Influential \\
Professional Growth and Development & 4.30 & 0.34 & Highly Influential \\
Promotions & 4.01 & 0.32 & Influential \\
Salaries & 3.53 & 0.38 & Influential \\
Rewards and Incentives & 3.88 & 0.33 & Influential
\end{tabular}

Legend: 1.0-1.80 (Not Influential), 1.81-2.60 (Slightly Influential), 2.61-3.40 (Moderately Influential), 3.41-4.20 (Influential), 4.21-5.0 (Highly Influential)

Table 1 shows the non-academic staff' perception on the different motivational factors assessed. Of the five factors, workplace environment and professional growth and development were considered 'highly influential' that motivates the personnel to improve their work performance. This signifies that the personnel have high regards to the different aspects of workplace environment such as safety and security, machine and technology and accessibility. Similarly, the value of professional growth and development is considered to be important for the improvement of work performance. The results further show promotion, salaries and rewards and incentives to be influential to the non-academic staff. Overall, all the factors assessed were considered motivational with varying degrees of influence on the work performance of the employees.

The analysis of the various individual indicators showed strong consideration of workplace ventilation and security $(\bar{x}=4.60)$, training on serving stakeholders and employee relationship ( $\bar{x}=4.36)$, criteria for promotion $(\bar{x}=4.14)$, salary based on workload $(\bar{x}=3.76)$ and incentives based on job performance $(\bar{x}=4.12)$.

As argued by Chandrasekar (2011), workplace environment affects the employee morale, productivity and engagement - both positively and negatively. Similarly, the current study results show congruence with this argument. The non-academic staff consider the ventilation and security of the workplace as the primary motivation for better work performance. 
While Mizell (2010) insists on professional development related to the nature of job, the current results showed otherwise. It was generally clear that training programs play vital role that improves employee performance at the workplace. These also update employee's knowledge, enhance personal skills and help avoid managerial obsolescence. However, the non-academic staff were motivated by training that improves stakeholder and employee relationship. The results imply that the non-academic staff place more importance on the nature of general services provided to the stakeholders as well as the inter-relation with other employees instead of particular training on the job nature and function. It was also evident that these employees are more into service-oriented trainings than technical trainings.

In terms of promotion, the personnel look for the clarity on the policies and the proper implementations of the criteria for promotion. These are the similar to the concepts of Turk (2008) on the use of well-functioning performance appraisal system in the organizational setting. While the academic staff employ clear criteria for ranking and promotion, the nonacademic staff are rated differently. The results refute the study of Archibong, et.al (2010) on the dissatisfaction of the academic staff on rating criteria for promotion in Nigerian universities. The current study upholds that the criteria for promotion in the research locale are motivating factors for the non-academic personnel.

The various indicators of salaries as motivating factors (Appendix D) confirm the findings of Pigors and Meyer (2007) on salary based on outputs. The respondents are motivated by the rate of salary commensurate to the amount of workload. This is congruent to the rewards and incentives indicator that employee perceived to be based on job performance. As stated by Baskar (2015) that recognition whether financial or non-financial makes employees feel valued and appreciated. Personnel who achieve monetary and non-monetary gains based on their performance are highly motivated to improve their work.

\section{Table 2}

\section{Self-perception on Job Performance}

\begin{tabular}{cccc}
\hline Factors & $\overline{\boldsymbol{X}}$ & SD & VI \\
\hline Quality & 4.47 & 0.11 & Strongly Agree \\
Quantity & 4.48 & 0.11 & Strongly Agree \\
Attitude towards Work & 4.69 & 0.12 & Strongly Agree \\
\hline
\end{tabular}

Legend: 1.0-1.80 (Strongly Disagree), 1.81-2.60 (Disagree), 2.61-3.40 (Neither Agree Nor Disagree), 3.41-4.20 (Agree), 4.21-5.0 (Strongly Agree)

Table 2 reflects the self-perception of the non-academic personnel on their job performance. All the factors of job performance were rated with 'Strongly Agree' which signifies that the non-academic staff have high performance ratings. The high regards to the 
attitude towards work clearly imply on the level of motivation. It shows the commitment and dedication of the employees towards their job.

On the various indicators assessed (Appendix $\mathrm{F}-\mathrm{H}$ ), the work quality has a weighted mean of 4.47, work quantity with 4.48 and attitude towards work with 4.69. In terms of work quality, respondents strongly agreed on maintaining lower chance of error and be accurate on the job or task. As an indicator of work quality, accuracy and precision on work of an employee are seen contributory to quality. The respondents also strongly agree that tasks given were finished on time. The self-perception of the employees on their work quality can be attributed to the highest regard to attitude towards work and co-workers. The non-teaching staff affirmed to possess positive attitude towards their work and willing to share positive thoughts to their co-workers. As explained by Ahmed (2019) that a positive attitude gives employees confidence, empowerment, and joy.

\section{Table 3}

Correlation between Motivational Factors and Quality of Work

\begin{tabular}{|c|c|c|c|}
\hline Variables & r-value & p-value & Interpretation \\
\hline Workplace Environment & $0.313^{*}$ & 0.027 & Significant \\
\hline Professional Growth and Development & $0.596^{* *}$ & 0.000 & Significant \\
\hline Promotions & $0.321^{*}$ & 0.023 & Significant \\
\hline Salaries & $0.338^{*}$ & 0.016 & Significant \\
\hline Rewards and Incentives & $0.475^{* *}$ & 0.000 & Significant \\
\hline
\end{tabular}

Table 3 exhibits the relationship between the motivational factors and work quality of the non-teaching staff which showed the former and the latter are significantly correlated. These resulted to the r-values of .313 and p-value of .027 (workplace environment), r-value of .596 and p-value of .000 (professional growth and development), r-value of .321 and p-value of .023 (promotion), r-value of .338 and p-value .016 (salaries), and r-value of .475 and pvalue of .000 (incentives and rewards). All the motivational factors highly affect the work quality of the non-academic staff. Relatively, the positive relationship signify that as the motivation increases the work quality also increase.

The findings are similar to the cited studies such as Muchtar (2016), Naharuddin (2013), Norlina, et.al (2020) and Bushiri (20214) on the positive effect of work environment to work performance; Rinny, Purba and Handiman (2020), Rahayu (2017), Simanjuntak (2015) and Septiani (2015) on the positive influence of promotion on work performance; and Fauzi (2014), Hamran Mohamad et. al (2016) and Yuli Triana (2017) on the significant influence of compensation on work performance. Similarly, Morrow (2020) explained that employee motivation can increase employee productivity and employee performance in the workplace. 
Table 4

Correlation between Motivational Factors and Quantity of Work

\begin{tabular}{cccc}
\hline Variables & r-value & p-value & Interpretation \\
\hline Workplace Environment & $.379^{* *}$ & .007 & Significant \\
Professional Growth and Development & $.509^{* *}$ & .000 & Significant \\
Promotions & $.315^{*}$ & .026 & Significant \\
Salaries & $.381^{* *}$ & .006 & Significant \\
Rewards and Incentives & $.418^{* *}$ & .003 & Significant \\
\hline
\end{tabular}

Table 4 exhibits that the related motivational factors are significantly correlated to work quantity of the non-teaching staff. The statistical results showed workplace environment with r-value of .379 and p-value of .007, professional growth and development with r-value of .509 and p-value of .000, promotion with r-value of.315 and p-value of .026, salaries with rvalue. 381 and p-value.006, rewards and incentives with .418 and p-value of .003. These are all interpreted as statistically significant. These motivational factors are influential to the quantity of work achieved by the personnel. It is evident that both the quality and quantity of work are highly influenced by the motivational factors.

The results hold true of quality and quantity of work. While it is expected that employees with good performance can do more than what is expected from them, there are limited literature correlating the quality and quantity of work. However, the study of Bushiri (2021) that the workplace environment enables employees to solve problems thereby increasing their ability to produce more. Similarly, Hamlin (2019) stressed that by rewarding employees, it spurs people to work harder and be more productive.

\section{Table 5}

Correlation between Motivational Factors and Attitude towards Work

\begin{tabular}{cccc}
\hline Variables & r-value & p-value & Interpretation \\
\hline Workplace Environment & .258 & .070 & Not Significant \\
Professional Growth and Development & $.468^{* *}$ & .001 & Significant \\
Promotions & .267 & .061 & Not Significant \\
Salaries & .089 & .540 & Not Significant \\
Rewards and Incentives & .089 & .322 & Not Significant \\
\hline
\end{tabular}

Table 5 reflects the correlation between the motivational factors and the attitude towards work. Of the variables tested, only the professional growth and development has the 
significant positive relationship to attitude towards work with an r-value of 0.468 and p-value of .001. This means that the trainings provided by the University influence the personnel to be positive towards their work. These professional growth and development factors develop the employees' attitude to be passionate and committed towards their positions.

The relationship between attitude towards work and professional growth and development could be related to the idea of Truitt (2011) that training programs reduce performance disputes. If there are less disputes, there are less complaints from the employees. Similarly, Raja, Furqan and Muhammad (2011) believe that training develops interpersonal skills enabling personnel to collaborate and work together to achieve organization and personal goals. This is further explained by Post (2019) that positive attitude in the workplace will not necessarily make better employee but will improve the way people view another person. For this, people will be more inclined to help each other succeed.

\section{Conclusion}

This descriptive study evaluated the relationship between the motivational factors and work performance of the 50 non-academic staff of a public university in San Pablo City in the Philippines. The self-structured questionnaire assessed the self-perception of the personnel on the motivation factors in terms of workplace environment, professional growth and development, advancement and salaries and benefits and job performance in terms of quality, quantity and attitude towards the job. Frequency count, weighted mean and Pearson $-r$ were used for data analysis.

The results of the study proved that the workplace environment and professional growth and development are considered highly influential whereas promotions, salaries and rewards and incentives as influential. Meanwhile, the personnel strongly agree on their work performance in terms of quality, quantity and attitude towards their job. There is a positive significant relationship between the motivational factors and job performance as to quantity and quality of work. It also confirmed that professional growth and development has significant relations with the attitude towards work. Indeed, motivational techniques are needed to sustain the work quantity and quality as well as enhance the positive attitude of the employees.

The results of this study can be an input to the University Human Resource planning. As the personnel emphasized the need for professional growth and development than monetary and non-monetary gains, the institution can formulate plans on the continuing professional development of the employees whether academic or non-academic. Since the major focus of any higher education institution is on the development of its teaching staff, it is definitely high time to formulate training programs for the administration and support staff. Since the study is focused only on a single university, a comparative study with another higher education 
institution is recommended for comparison. Moreover, other motivational factors and job performance can be incorporated as additional variables for a more comprehensive assessment.

\section{Appendices}

\section{Appendix A \\ Motivational Factors as to Workplace Environment}

\begin{tabular}{lccc}
\hline \multicolumn{1}{c}{ Indicators } & $\mathrm{M}$ & $\mathrm{SD}$ & $\mathrm{VI}$ \\
\hline 1. The workplace ventilation and security & 4.60 & .495 & Highly Influential \\
2. Workplace equipment/machine for the job & 4.22 & .737 & Highly Influential \\
3. The workplace accessibility & 4.50 & .580 & Highly Influential \\
4. The workplace conduciveness to the employees and the clientele & 4.42 & .538 & Highly Influential \\
5. Rules and policies observed in the office & 4.46 & .613 & Highly Influential \\
$\quad$ Over-all mean & $\mathbf{4 . 4 4}$ & $\mathbf{0 . 5 9 3}$ & Highly Influential \\
\hline
\end{tabular}

\section{Appendix B}

Motivational Factors as to Professional Growth and Development

\begin{tabular}{lccc}
\hline \multicolumn{1}{c}{ Indicators } & M & SD & VI \\
\hline 1. The office training opportunities for everyone & 4.18 & .719 & Influential \\
2. Mentoring of superior to employees who needs training & 4.26 & .803 & Highly Influential \\
3. Training on developing new ways to serve stockholders & 4.36 & .663 & Highly Influential \\
4. Career progression in the office & 4.34 & .626 & Highly Influential \\
5. Relationship between employees & 4.36 & .563 & Highly Influential \\
Over-all mean & $\mathbf{4 . 3 0}$ & & Highly Influential \\
\hline
\end{tabular}

\section{Appendix C}

Motivational Factors as to Promotion

\begin{tabular}{lccc}
\hline \multicolumn{1}{c}{ Indicators } & M & SD & VI \\
\hline 1. Policies observed in promotions & 4.10 & .763 & Influential \\
2. Criteria followed in promotion & 4.14 & .700 & Influential \\
3. Qualified employees entitlement to promotion & 4.08 & .695 & Influential \\
4. Information dissemination on promotion & 3.78 & .737 & Influential \\
5. Enthusiasm towards work promotion & 3.94 & .935 & Influential \\
$\quad$ Over-all mean & $\mathbf{4 . 0 1}$ & $\mathbf{0 . 7 7}$ & Influential \\
\hline
\end{tabular}

\section{Appendix D}

Motivational Factors as to Salaries

\begin{tabular}{lccc}
\hline \multicolumn{1}{c}{ Indicators } & M & SD & VI \\
\hline 1. Salary based on the work load & 3.76 & 1.00 & Influential \\
2. Appraisal of salary based on the performance & 3.70 & .953 & Influential \\
3. Overtime rendered paid accurately & 3.36 & 1.17 & Influential \\
4. Enough salary to support the family needs & 3.42 & .992 & Influential \\
5. Salary inclease & 3.42 & 1.05 & Influential \\
& $\mathbf{3 . 5 3}$ & $\mathbf{1 . 0 3}$ & Influential \\
\hline
\end{tabular}


International Journal of Academe and Industry Research, Volume 2 Issue 3

Appendix E

Motivational Factors as to Incentives and Rewards

\begin{tabular}{|l|l|c|c|}
\hline \multicolumn{1}{|c|}{ Indicators } & M & SD & VI \\
\hline 1.Incentives given to deserving employees & 3.78 & .975 & Influential \\
\hline 2. Overtime pay given to deserving employees & 3.40 & 1.16 & Influential \\
\hline 3. Incentives for productive employees & 4.04 & .879 & Influential \\
\hline 4. Rewards and incentives for work performance & 4.06 & .935 & Influential \\
\hline 5. Incentives and rewards for employee attitude & 4.12 & .8243 & Influential \\
\hline \multicolumn{1}{|c|}{ Over-all mean } & $\mathbf{3 . 8 8}$ & $\mathbf{. 9 5 4 6}$ & Agree \\
\hline
\end{tabular}

Appendix F

Job Performance as to Quantity

\begin{tabular}{|l|l|l|l|}
\hline \multicolumn{1}{|c|}{ Indicators } & M & SD & VI \\
\hline 1. I finish my job on time. & 4.56 & .541 & Strongly agree \\
\hline 2. I met the deadlines given by the superior & 4.48 & .614 & Strongly agree \\
\hline 3. The duties are done in the allotted time & 4.50 & .614 & Strongly Agree \\
\hline 4. There's an increase in production level & 4.40 & .756 & Strongly Agree \\
\hline 5. Extra duties are being completed on time. & 4.46 & .706 & Strongly Agree \\
\hline \multicolumn{1}{|c|}{ Over-all mean } & $\mathbf{4 . 4 8}$ & $\mathbf{0 . 9 5}$ & Strongly Agree \\
\hline
\end{tabular}

\section{Appendix G}

Job Performance as to Quality

\begin{tabular}{|c|c|c|c|}
\hline Indicators & $\mathbf{M}$ & SD & VI \\
\hline 1. Meets basic productivity requirements & 4.44 & .577 & Strongly Agree \\
\hline 2. Maintain the accuracy of work & 4.56 & .541 & Strongly Agree \\
\hline 3. Never neglects any details of tasks given & 4.46 & .543 & Strongly Agree \\
\hline 4. No error were incurred in doing one's duties & 4.38 & .697 & Strongly Agree \\
\hline 5. Never ignores any detail in work & 4.52 & .647 & Strongly Agree \\
\hline Over-all mean & 4.47 & 0.60 & Strongly agree \\
\hline
\end{tabular}

\section{Appendix $\mathbf{H}$}

Job Performance as to Attitude towards Job

\begin{tabular}{|c|c|c|c|}
\hline Indicators & $\mathbf{M}$ & SD & VI \\
\hline 1. I am always positive in doing my work & 4.76 & .431 & Strongly Agree \\
\hline 2. Willing to share positive thoughts which are refreshing & 4.72 & .454 & Strongly Agree \\
\hline 3. Possesses strong personality & 4.60 & .571 & Strongly Agree \\
\hline 4. Have passion in job & 4.68 & .513 & Strongly Agree \\
\hline 5. Maintain honesty in every transaction & 4.70 & .505 & Strongly Agree \\
\hline Over-all mean & 4.69 & 0.49 & Strongly agree \\
\hline
\end{tabular}

\section{References}

Adi, I Gede Purnawan; I Wayan Bagia, dan Wayan Cipta. (2016). "Pengaruh Promosi Jabatan dan Disiplin Kerja terhadap Kinerja Pegawai”. e-Journal Bisma Universitas Pendidikan Ganesha. Vol.4.

Ahmed, A. (2019). The Importance of a Good Attitude on the Job. Retrieved on July 4, 2021, from https://bizfluent.com/about-7277260-importance-good-attitude-job.html 
Aideed Bashir, Abeera Amir, Mehwish Jawaad \& Tania Hasan | Richard Wickramaratne (Reviewing editor) (2020) Work conditions and job performance: An indirect conditional effect of motivation, Cogent Business \& Management, 7:1, DOI: $10.1080 / 23311975.2020 .1801961$

Archibong, I. A., Effiom, D. O., Omoike, D., \& Edet, A. O. (2010). Academic Staff Disposition To Promotion Criteria In Nigerian Universities. Journal of College Teaching \& Learning (TLC), 7(10). https://doi.org/10.19030/tlc.v7i10.153

Asaari M. \& Desa N. (2019). Influence of Salary, Promotion, and Recognition toward Work Motivation among Government Trade Agency Employees. International Journal of Business and Management 14(4):48. DOI: 10.5539/ijbm.v14n4p48

Baskar, P. (2015). A Study on the Impact of Rewards and Recognition on Employee Motivation. International Journal of Science and Research. Volume 4 Issue 11.

Bullock, J. B., Stritch, J. M., \& Rainey, H. G. (2015). International Comparison of Public and Private Employees' Work Motives, Attitudes, and Perceived Rewards. Public Administration Review, 75(3), 479-489. https://doi.org/10.1111/puar.12356

Bushiri, C.P. (2014). The Impact of Working Environment on Employees' Performance: The Case of Institute Of Finance Management in Dar Es Salaam Region. A Dissertation Submitted In the Open University of Tanzania

Doan Hong Lea, Perfecto G. Aquino, Revenio C. Jalagat Jr., Nguyen Thanh Truc , Le Khac Quang Sid and Le Thi Hoang Mye (2021). Factors affecting employees' motivation. Management Science Letters 11 (2021) 1063-1070. DOI: 10.5267/j.msl.2020.11.033

Elmi, Farida. (2018). Telisik Manajemen Sumber Daya Manusia. Penerbit Mitra Wacana Media. Jakarta

Eshun, C. \& Duah, F. (2011). Rewards as a motivation tool for employee performance. A Thesis presented to the School of Management. Blekinge Institute of Technology.

Fauzi, Usman. (2014). "Pengaruh Kompensasi terhadap Kinerja Karyawan pada PT. Trakindo Utama Samarinda”. eJournal Ilmu Administrasi Bisnis. Vol. 2. No.3. ISSN 2355-5408. Hal. 172-185.

Freden S. Delgado, Felyn Mae G. Yap, Rosemarie L. Luces (2018); Level of Work Motivation: Its Relationship to Job Performance of Non-academic Staff at CapSU System; International Journal of Scientific and Research Publications (IJSRP) 8 (9), DOI: http://dx.doi.org/10.29322/IJSRP.8.9.2018.p8133

Gichure, C. (2014). Factors Influencing Employee Motivation and Its Impact on Employee Performance: A Case of Amref Health Africa in Kenya. A Research Project Report Submitted to Chandaria School of Business

Gupta, C. B. (2011). Human Resource Management. New Delhi: Sultan Chand \& Sons 
Hamlin, K. (2019, March 20). The Role of a Reward in Employee Motivation. Retrieved July 4, 2021, from https://smallbusiness.chron.com/role-reward-employee-motivation$\underline{18814 . h t m 1}$

Hasibuan, Malayu S.P. (2018). Manajemen Sumber Daya Manusia. PT Bumi Aksara. Jakarta.

Kosteas V, (2009). Job satisfaction and promotions. A Thesis presented to Cleveland State University.

Lau, Wing Keung Jason. "Empowerment of non-academic personnel in higher education: exploring associations with perceived organizational support for innovation and organizational trust." PhD (Doctor of Philosophy) thesis, University of Iowa, 2010. https://doi.org/10.17077/etd.nua1b3wl

Mohamad, Mohd Hamran; Khulida Kirana Yahya, Suhaimi Ishak, dan Rashid Nordin. (2016). "The Influence of Compensation Practice on Performance of Enforcement Employees". Journal of Global Business and Social Entrepreneurship (GBSE). Vol.1. No.2. e-ISSN 24621714. Hal 39-45.

Morrow, B. M. K. (2020, August 6). A Look into Motivation and How it Impacts Productivity. Retrieved July 4, 2021, from https://zipchecklist.com

Muchtar, M. (2016). The Influence of Motivation And Work Environment On The Performance Of Employees University. Sinergi, Volume 6, Number 2. DOI: 10.25139/sng.v6i2.80

Naharuddin, Nina and Sadegi, Mohammad (2013). Factors of Workplace Environment that Affect Employees Performance: A Case Study of Miyazu Malaysia. International Journal of Independent Research and Studies, 2(2), 66-78

Norlina, M. N., Puteri, F. A. Z., Abang, F. A. M. \& Imelda, N. (2020). Job Performance and Employee Motivation among Non-Academic Staff at a Public University in Sarawak, Malaysia. Jurnal Penyelidikan Sains Sosial (JOSSR), 3(6), 109 - 119.

Norlina, M. N., Puteri, F. A. Z., Abang, F. A. M. \& Imelda, N. (2020). Job Performance and Employee Motivation among Non-Academic Staff at a Public University in Sarawak, Malaysia. Jurnal Penyelidikan Sains Sosial (JOSSR), 3(6), 109 - 119.

Ogunode Niyi Jacob, Ahaotu, Godwin Ndubuisi, \& Ajape Temitope Solomon. (2021). Problems Faced By Non Academic Staff Of Nigerian Public Universities And The Way Forward. Academicia Globe: Inderscience Research, 2(6), 176-184. https://doi.org/10.17605/OSF.IO/QHC3R

Post, J. (2019). How to Develop a Positive Attitude in the Workplace. Retrieved July 4, 2021, from https://www.businessnewsdaily.com/6912-develop-positive-mindset.html

Puspita Rinny, Charles Bohlen Purba, Unang Toto Handiman (2020). The Influence Of Compensation, Job Promotion, And Job Satisfaction On Employee Performance Of Mercubuana University. International Journal of Business Marketing and Management (IJBMM) Volume 5 Issue 2, pp. 39-48 
Rahayu, Suharni. (2017). "Pengaruh Promosi Jabatan Terhadap Kinerja Karyawan pada PT. Garuda Metalindo". Jurnal KREATIF : Pemasaran, Sumberdaya Manusia dan Keuangan. Vol.5. No.1. ISSN 2339 - 0689. Hal 59-75.

Rahman, M. M., \& Hoque, M. M. (2014). An Analysis of Employee Job Satisfaction: A Study on United Commercial Bank Limited. International Journey of Ethics in Social Sciences, 2(2), 117-131.

Raja, A. G., and Furqan, A. K., Muhammad, A. K. (2011) 'Impact of Training and Development on Organisational Performance', Global Journal of Management and Business Research, Vol. 11, No. 7, pp.45-62.

Scott, S. (2019). Rewards and Incentives in the Workplace. Retrieved July 4, 2021, from https://smallbusiness.chron.com/rewards-incentives-workplace-11236.html

Seng, E. L. K.., Choi Wai, C. (2016). "An Empirical Study of Academic and Non-academic Staff's Job Satisfaction and Organizational Commitment in an Institute of Higher Learning”, Journal of Entrepreneurship, Business and Economics, Vol. 4, No. 1, pp. 45-72.

Septiani, Virginia Maulidiah. (2015). "Pengaruh Pelatihan, Pengalaman Kerja, dan Promosi Jabatan terhadap Kinerja Karyawan pada Badan Pemeriksa Keuangan Republik Indonesia Perwakilan Sulawesi Utara". Jurnal EMBA: Jurnal Riset Ekonomi, Manajemen, Bisnis, dan Akuntansi. Vol.3. No.3. ISSN 2303-11. Hal 992-1002.

Simanjuntak, Winda Yulyarta. (2015). "Pengaruh Promosi Jabatan terhadap Kinerja Karyawan pada PT. Riau Media Grafika/Tribun Pekanbaru”. Jurnal Online Mahasiswa Fakultas Ilmu Sosial dan Ilmu Politik. Vol.2. No.2. Hal 1-12

Snacknation, (2018). Effective Ways to Motivate Employees. Retrieved from: http://wwwsnacknation.comeffective-ways-tomotivate-employees-oct.2018

Töre, E. (2021). Effects of Teacher Emotional Labor on Job Performance: Mediating Role of Job Satisfaction, International Journal of Education Technology and Scientific Researches, 6(15), 945- 976. http://dx.doi.org/10.35826/ijetsar.261

Triana, Yuli. (2017). "The Influence of Compensation, Organizational Commitment and Career Path to Job Performance Employees”. Jurnal Aplikasi Manajemen. Vol.15. No.1. Hal 68-73.

Villagrasa, P. R, et al., (2019). Assessing Job Performance Using Brief Self-Report Scales: The Case of the Individual Work Performance Questionnaire. Journal of Work and Organizational Psychology, Vol. 35, Num. 3, pp 195-205. https://doi.org/10.5093/jwop2019a21

Wanjiku, Wachira Gladys (2016). Factors Affecting Non-Teaching Staff Development in Kenyan Universities. International Journal of Academic Research in Business and Social Sciences, Vol. 6, No. 5, http://dx.doi.org/10.6007/IJARBSS/v6-i5/2120 